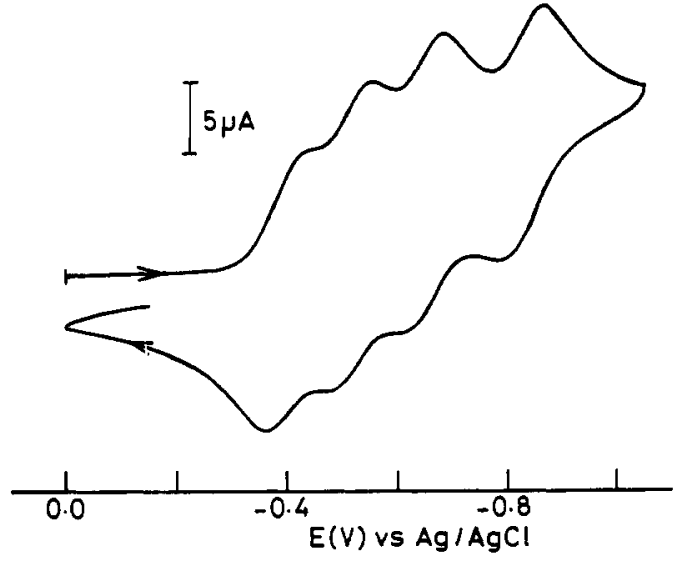

Figure 5. Cyclic voltammogram of $\left.1.0 \mathrm{mmol} \mathrm{dm}^{-3}\left[\{\mathrm{Co} \text { (aet) })_{3}\right\}_{4} \mathrm{Zn}_{4} \mathrm{O}\right]^{6+}$ (cation of 2) in $0.1 \mathrm{~mol} \mathrm{dm}^{-3}$ aqueous solution of $\mathrm{NaNO}_{3}$. The scan rate is $50 \mathrm{mV} \mathrm{s}^{-1}$.

region (32-48) $\times 10^{3} \mathrm{~cm}^{-1}$ (Figure 3). This $\mathrm{CD}$ spectral deviation suggests that the asymmetric bridging sulfur atoms of the central $\mathrm{CoS}_{6}$ chromophore in $\Delta \Delta-\left[\mathrm{Co}\left\{\mathrm{Co}(\mathrm{aet})_{3}\right\}_{2}\right]^{3+}$ contribute conspicuously to the $C D$ spectrum in the region $(16-30) \times 10^{3} \mathrm{~cm}^{-1}$.

Electrochemical experiments were performed in a $0.1 \mathrm{~mol} \mathrm{dm}^{-3}$ $\mathrm{NaNO}_{3}$ aqueous solution at a glassy carbon electrode. As shown in Figure 5 , the cyclic voltammogram of $\left[\left\{\mathrm{Co}(\text { aet })_{3}\right\}_{4} \mathrm{Zn}_{4} \mathrm{O}\right]^{6+}(2)$ initiated at $0.0 \mathrm{~V}$ with a negative potential scan yields four consecutive reduction waves $\left(E_{\mathrm{pc}}=-0.44,-0.56,-0.69,-0.87 \mathrm{~V}\right)$ and coupled four oxidation waves $\left(E_{\text {pa }}=-0.36,-0.48,-0.61\right.$, and -0.79 V). No other redox couple is observed in the potential region of +0.8 to $-1.2 \mathrm{~V}$ (vs $\mathrm{Ag} / \mathrm{AgCl}$ ). The peak current is approximately proportional to the square root of the scan rate. At a scan rate of $50 \mathrm{mV} \mathrm{s}^{-1}$, the ratio of cathodic to anodic peak current is approximately unity and the observed peak separation $\left(E_{\mathrm{pc}}-E_{\mathrm{pa}}\right)$ is $80 \mathrm{mV}$ for each redox couple. These results establish that the four redox processes which occur at $E^{\circ \prime}=-0.40,-0.52,-0.65$, and $-0.83 \mathrm{~V}$ are electrochemically quasi-reversible. For the corresponding $\mathrm{Rh}^{\mathrm{III}} \mathrm{Zn}^{\mathrm{II}}$ complexes, [ $\left.\left[\mathrm{Rh}(\mathrm{aet}){ }_{3}\right\}_{4} \mathrm{Zn}_{3} \mathrm{O}\right]^{4+}$ and $\left[\left\{\mathrm{Rh}(\mathrm{aet})_{3}\right]_{4} \mathrm{Zn}_{4} \mathrm{O}\right]^{6+}, 4,5$ no redox reaction has occurred in the region of +0.8 to $-1.2 \mathrm{~V}$ under the same condition. Therefore, the four redox processes can be assigned as the stepwise reactions as follows:

$$
\begin{aligned}
& \mathrm{Co}^{\mathrm{III}} \mathrm{Zn}_{4} \mathrm{II}_{4} \rightleftharpoons \mathrm{Co}_{3}{ }_{3} \mathrm{Co}^{\mathrm{II}} \mathrm{Zn}_{4}{ }_{4} \rightleftharpoons \mathrm{Co}_{2}{ }_{2} \mathrm{Co}_{2}{ }_{2} \mathrm{Zn}_{4} \rightleftharpoons \\
& \mathrm{Co}^{\mathrm{III}} \mathrm{Co}^{\mathrm{II}}{ }_{3} \mathrm{Zn}_{4} \mathrm{II} \rightleftharpoons \mathrm{Co}_{4}{ }_{4} \mathrm{Zn}^{\mathrm{II}}
\end{aligned}
$$

In order to estimate the structure of 1 , its cyclic voltammetric measurement was performed under the same conditions as used for 2. The cyclic voltammogram of 1 gave broad and nonreversible four consecutive reduction waves at $E_{\mathrm{pc}}=-0.45,-0.57,-0.71$, and $-0.89 \mathrm{~V}$. This electrochemical behavior analogies with that of 2, although the relative instability of 1 in water restricts the electrochemical characterization. In addition, the absorption spectrum of 1 is quite similar to that of 2 over the whole region, as shown in Figure 4. These facts suggest that 1 has a cage-type $\mathrm{S}$-bridged structure similar to that of 2 . The plasma emission spectral analysis indicates that 1 contains $C_{0}$ and $\mathrm{Zn}$ in a ratio of 4:3. Accordingly, it is likely that 1 is the cage-type S-bridged complex with a "defective" $\left[\mathrm{Zn}_{3} \mathrm{Br}\right]^{\mathrm{s+}}$ core, $\left[\left[\mathrm{Co}(\mathrm{aet})_{3}\right\}_{4} \mathrm{Zn}_{3} \mathrm{Br}\right]^{s+}$, considering that the formation of 1 was achieved by the addition of a large amount of $\mathrm{NaBr}$ to the reaction solution of $f a c(S)$ $\left[\mathrm{Co}(\text { aet })_{3}\right]$ and $\mathrm{Zn}^{2+}$.

Registry No. 1, 139100-76-8; $2 \cdot \mathrm{Br}_{6}$ ( $\Lambda$-isomer), 139100-77-9; 2 . $\mathrm{Br}_{6} \cdot 9.5 \mathrm{H}_{2} \mathrm{O}$ ( $\Lambda$-isomer), 139236-12-7; $2^{6+}$ ( $\Delta$-isomer), 139236-13-8; fac-(S)-[Co(aet $\left.)_{3}\right], 18703-22-5 ; \Delta \Delta-\left[\mathrm{Co}\left\{\mathrm{Co}(\text { aet })_{3}\right\}_{2}\right]\left(\mathrm{NO}_{3}\right)_{3}, 129387-95-7$; $\Delta_{\mathrm{LLL}}-f a c(S)-\mathrm{K}_{3}\left[\mathrm{Co}(\mathrm{L}-\mathrm{cys}-N, S)_{3}\right], 97860-43-0$.

Supplementary Material Available: Table SI, listing anisotropic thermal parameters (1 page); Table SII, listing observed and calculated structure factors (8 pages). Ordering information is given on any current masthead page.

Contribution from the Department of Chemistry, National Taiwan University, Taipei, Taiwan, ROC

\title{
Synthesis and Characterization of Pillared Buserite
}

\author{
She-Tin Wong and Soofin Cheng* \\ Received July 19, 1991 \\ Synthetic Na-buserite, a layered manganese oxide formulated as $\mathrm{Na}_{4} \mathrm{Mn}_{14} \mathrm{O}_{26} \cdot \times \mathrm{H}_{2} \mathrm{O}$, was pillared with polyoxo cations of aluminum \\ known widely as Keggin ions, $\left[\mathrm{Al}_{13} \mathrm{O}_{4}(\mathrm{OH})_{24}\left(\mathrm{H}_{2} \mathrm{O}\right)_{12}\right]^{7+}$, with a diameter of $8.6 \mathrm{~A}$. The synthetic Na-buserite was first expanded \\ with $n$-hexylammonium cations to produce hexylammonium ion-expanded buserite. This process expands the buserite interlayer \\ free spacing from 1.94 to $12.94 \AA$, thus allowing subsequent ion-exchange reaction with Keggin ions to proceed. The presence \\ of pillars between the interlayers of the buserite structure was confirmed by $\mathrm{X}$-ray diffraction, thermogravimetric analysis, and \\ surface area measurements. $\mathbf{N}_{2}$ adsorption-desorption studies showed that the Keggin ion-pillared buserites are microporous in \\ nature. Particular interest was focused on the studies of the thermal stability of the various materials in different gaseous \\ environment. By complementary studies between X-ray diffraction and thermogravimetric analysis, the intermediates and the \\ final products of these reactions can be identified.
}

\section{Introduction}

In the search and development of new and more efficient catalysts for use in the petroleum-related industry in particular, pillared compounds have gradually emerged as an important potential alternative to the presently available industrial catalysts. ${ }^{1,2}$ Among the available layered compounds, pillared clays have received the most attention and seem to have great potential in the area of acid catalysis such as cracking. ${ }^{1,3}$ On the other hand, the pillared derivatives of layered metal oxides, such as double hydroxide, $4,5 \mathrm{Li}_{x} \mathrm{MoO}_{3}, 6$ and $\mathrm{K}_{2} \mathrm{Ti}_{4} \mathrm{O}_{9}^{7}$ etc., although receiving

(1) Figueras, F. Catal. Rev.-Sci. Eng. 1988, 30, 457.

(2) Nitta, M. Appl. Catal. 1984, 9, 151

(3) Vaughan, D. E. W. Catal. Today 1988, 2, 187 relatively less attention than pillared clays, have great potential to be important catalytic materials.

Most Mn oxides can be produced by a variety of pathways, and interconversions between different oxides form an important feature of this class of compounds. ${ }^{8}$ Birnessite, which is a partially dehydrated form of buserite, is widely distributed in soils and sediments. It is one of the important components of manganese

(4) Drezdzon, M. A. Inorg. Chem. 1988, 27, 4628

(5) Pinnavaia, T. J.; Kwon, T.; Tsigdinos, G. A. J. Am. Chem. Soc. 1988 110,3653

(6) Nazar, L. F.; Liblong, S. W.; Yin, X. T. J. Am. Chem. Soc. 1991, 113 5889.

(7) Cheng, S.; Wang, T. C. Inorg. Chem. 1989, 28, 1283.

(8) Giovanoli, R. Chimia 1976, 30, 102. 

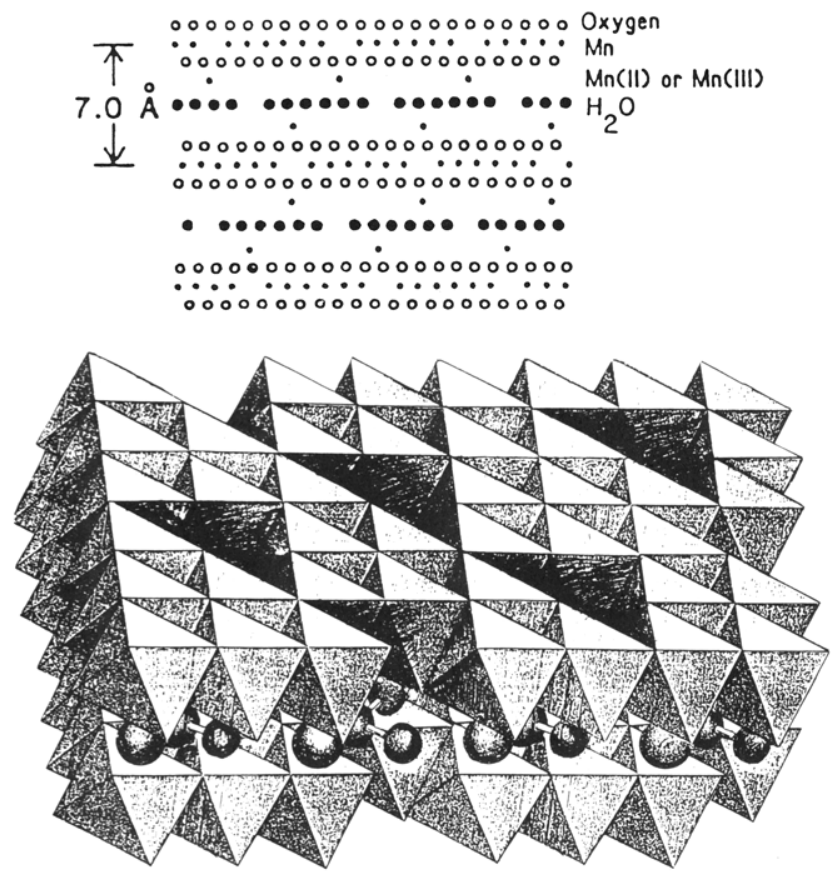

Figure 1. (a) Top: Na-buserite structure as seen in a section perpendicular to the $b$-axis. Reprinted with permission from ref 12 . Copyright 1986 Clays and Clay Minerals. (b) Bottom: Three-dimensional representation of the $\mathrm{Na}$-buserite structure.

nodules, which are abundant on ocean floor. ${ }^{2}$ The relatively high surface area and transition metal oxide content were some of the main attractions for the study of its possible use as catalyst and adsorbent. Manganese nodules have been found to be as effective as some commercial catalysts and adsorbents. ${ }^{2}$ Therefore, it may provide a cheap substitute for some commercial catalysts in the near future. This provides us an incentive to study $\mathrm{Na}$-buserite.

The chemistry, structure, and other properties of natural birnessite and its cation-exchange derivatives are not well understood. In the classification scheme of Burns and Burns, ${ }^{9-11}$ the structure of birnessite is modeled after that of chalcophanite. In this model, birnessite has a layered structure, probably consisting of sheets of water molecules between sheets of edge-sharing $\mathrm{MnO}_{6}$ octahedra (Figure 1a). ${ }^{12}$ A three-dimensional representation of the structure is shown in Figure $1 \mathrm{~b}$. One out of six octahedral sites in the sheet of $\mathrm{MnO}_{6}$ octahedra is unoccupied, hence, the excess anionic charge must be balanced by cations. These cations include $\mathrm{Mn}^{2+}$ and $\mathrm{Mn}^{3+}$ ions which originated from the source of manganese in the synthesis of birnessite. They lie above and below each octahedral vacancy. These low-valence Mn cations are coordinated to oxygens in both the octahedra $\mathrm{MnO}_{6}$ sheet and the water sheet. Other cations such as $\mathrm{Na}^{+}$and $\mathrm{K}^{+}$may be present also, depending on the method of synthesis. The synthetic bir-

Scheme I

$$
\mathrm{MnCl}_{2}(\mathrm{aq})+\mathrm{O}_{2}(\mathrm{~g})+\mathrm{NaOH}(\mathrm{aq}) \stackrel{\text { room temp }}{\longrightarrow} \mathrm{Na}_{4} \mathrm{Mn}_{14} \mathrm{O}_{26} \cdot x \mathrm{H}_{2} \mathrm{O}
$$

(9) Burns, R. G.; Burns, V. M. Philos. Trans. R. Soc. London 1977, A286, 283

(10) Burns, R. G.; Burns, V. M. In Manganese Dioxide Symposium; Kozawa, A.; Brodd, R. J., Eds.; The Electrochemical Society: Cleveland, OH, 1975; Vol. 1; p 306.

(11) Burns, R. G.; Burns, V. M. Marine Manganese Deposits; Glasby, G P. Ed.; Elsevier: Amsterdam, 1977: Chapter 7.

(12) Golden, D. C.; Dixon, J. B.; Chen, C. C. Clays Clay Miner. 1986, 34, 511

(13) Giovanoli, R.; Buhler, H.; Sokolowska, K. J. Microsc. (Paris) 1973, 18 , 271.

(14) Giovanoli, R.; Stähli, E.; Feitknecht, W. Helv. Chim. Acta 1970, 53, 209

(15) Golden, D. C.; Chen, C. C.; Dixon, J. B. Clays Clay Miner. 1987, 35, 271

(16) Cornell, R. M.; Giovanoli, R. Clays Clay Miner. 1988, 36, 249.
Scheme II. Preparation of KPB

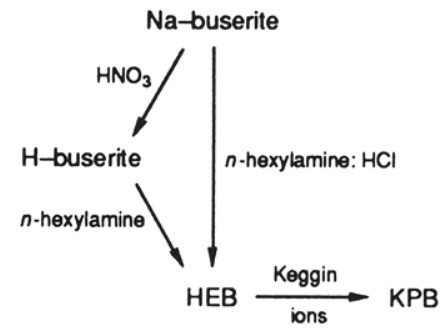

nessite has been reported to have a unit cell formula $\mathrm{Na}_{4} \mathrm{Mn}_{14^{-}}$ $\mathrm{O}_{26} \cdot 9 \mathrm{H}_{2} \mathrm{O}$ and is nonstoichiometric. ${ }^{13,14}$ In many cases however, the unit cell formula $\mathrm{Na}_{4} \mathrm{Mn}_{14} \mathrm{O}_{27} \cdot 9 \mathrm{H}_{2} \mathrm{O}$ was used. ${ }^{12,15,16}$ The difference may arise from both the variable oxidation state of $\mathrm{Mn}$ and the elemental analysis procedures. The layers of $\mathrm{MnO}_{6}$ octahedra are repeated along the $c$-axis, i.e., the axis perpendicular to the plane of the layers. The basal spacing of this compound may be $7 \AA$ (birnessite) or $10 \AA$ (buserite). Buserite is thus the fully hydrated form of birnessite.

For buserite to have potential applications in the area of catalysis, it must possess high surface area and thermal stability. To increase the surface area of a layered compound, e.g., clays, the most widely used technique is to introduce pillars between the interlayers. The Keggin ion with molecular formula $\left[\mathrm{Al}_{13} \mathrm{O}_{4^{-}}\right.$ $\left.(\mathrm{OH})_{24}\left(\mathrm{H}_{2} \mathrm{O}\right)_{12}\right]^{7+}$ is a large polyoxo cation which has been reported to be thermally stable at temperature more than $500^{\circ} \mathrm{C} .^{3}$ Since clay is capable of swelling in water, ${ }^{17}$ Keggin ion-pillared clay is normally prepared by a direct exchange method with the Keggin ion solution. Buserite and clay would have different charge densities and hence, a different pillaring technique may be needed. A possible way is to expand the interlayer spacing of buserite with organic compounds before introducing the Keggin ions. This technique has proved successful for a wide variety of layered compounds. ${ }^{7,18,19}$ The aim of this study is to utilize the stepwise pillaring technique on the layered manganese oxide and to characterize the physicochemical properties of the resultant compounds so that their applications in catalysis can be explored.

\section{Experimental Procedures}

Synthesis of Na-Buserite. The method of synthesis was adapted from stähli. 20 In this method (Scheme I), $200 \mathrm{~mL}$ of a $0.5 \mathrm{M} \mathrm{MnCl}_{2}$ solution was used and $\mathrm{O}_{2}$ was bubbled through it. The $\mathrm{O}_{2}$ flow was controlled at more than $2 \mathrm{~L} / \mathrm{min}$. A $250-\mathrm{mL}$ aliquot of a cold solution $\left(7^{\circ} \mathrm{C}\right)$ of $\mathrm{NaOH}(55 \mathrm{~g})$ was then quickly added. The oxygenation was maintained for further $5 \mathrm{~h}$. The black precipitate of Na-buserite formed was filtered, washed, and dried.

Cation-Exchange Capacity (CEC). $\mathrm{Mg}\left(\mathrm{NO}_{3}\right)_{2} \cdot 6 \mathrm{H}_{2} \mathrm{O}$ and $\mathrm{KNO}_{3}$ were used for the preparation of $\mathrm{Mg}$-buserite and $\mathrm{K}$-buserite, respectively, by ion-exchange. $\mathrm{Na}$-buserite was used as the starting material. The cationic charge concentration for each salt in the exchange solution was about 150 times in excess of $\mathrm{Na}^{+}$in $\mathrm{Na}$-buserite. The exchange process was carried out for at least 1 day at room temperature, and the process was repeated twice. The final product was carefully washed and dried. CEC was calculated on the basis of $\mathrm{K}$ (or $\mathrm{Mg}$ ) uptake in mequiv/100 $\mathrm{g}$ of dry $\mathrm{Na}$-buserite.

Preparation of Keggin Ion-Pillared Buserite. $N$-Hexylammonium ion-expanded buserite, abbreviated as HEB, was first prepared from $\mathrm{Na}$-buserite via two pathways as shown in Scheme II. In the one-step process, a $1 \mathrm{~N}$ solution of a mixture of $n$-hexylamine and $\mathrm{HCl}$ (mole ratio 1:1) was used. The $\mathrm{pH}$ of the solution was adjusted to 7 , and the exchange process was carried out at room temperature for at least 10 days. In the two-step process, the $\mathrm{Na}$-buserite was first exchanged with $1 \mathrm{~N}$ nitric acid at $70^{\circ} \mathrm{C}$ for $7 \mathrm{~h}$. The $\mathrm{H}$-buserite obtained then underwent a second neutralization step with $5 \mathrm{~N} n$-hexylamine at room temperature for 12 days. HEB was used to prepare Keggin ion-pillared buserite, abbreviated as KPB, by ion exchange with Keggin ion solution (Scheme II). In order to avoid the competition of other cations for the ion-exchange sites of buserite, the Keggin ion solution was prepared by using

(17) Fink, D. H.; Thomas, G. W. Soil Sci. Soc. Am. Proc. 1964, $28,747$.

(18) Clearfield, A.; Roberts, B. D. Inorg. Chem. 1988, 27, 3237.

(19) Landis, M. E.; Aufdembrink, B. A.; Chu, P.; Johnson, I. D.; Kirker, G. W.; Rubin, M. K. J. Am. Chem. Soc. 1991, 113, 3189.

(20) Stähli, E. Ph.D. Thesis; University of Bern, Bern Switzerland, 1968. 


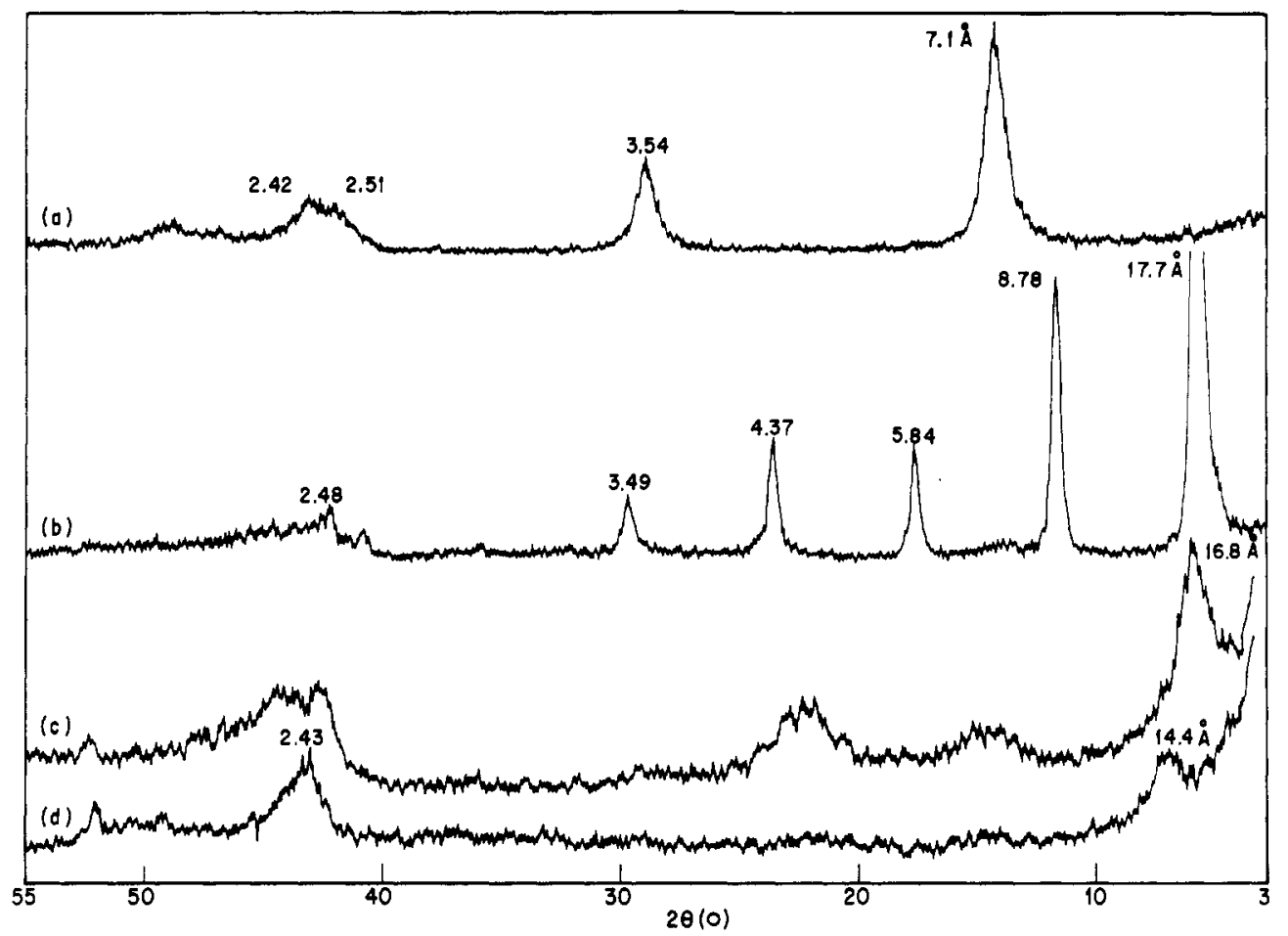

Figure 2. XRD patterns of (a) Na-buserite (b) HEB, and (c) KPB before calcination and (d) KPB after calcination at $300{ }^{\circ} \mathrm{C}$.

$n$-hexylamine to hydrolyze the aluminum chloride solution at $50^{\circ} \mathrm{C}$. In order to keep the solution clear at all time, $n$-hexylamine was added dropwise to the aluminum chloride solution over a period of 3-4 days. When the solution reached a $\mathrm{pH}$ between 4.1 and 4.2 , it was filtered and aged at $50^{\circ} \mathrm{C}$ for $2 \mathrm{~h}$ before being used for the exchange reaction. A $1-\mathrm{g}$ sample of HEB powder in $300 \mathrm{~mL}$ of exchange solution was used. The exchange temperature and solution concentration were normally 50 ${ }^{\circ} \mathrm{C}$ and $0.6 \mathrm{~N}$ (in terms of $\mathrm{Al}$ ), respectively, unless otherwise stated. The product obtained was calcined in air at $300^{\circ} \mathrm{C}$ for $2 \mathrm{~h}$ before it was used for further study.

Characterization Techniques. In the elemental analysis, $10 \mathrm{mg}$ of the sample was first dissolved in $4 \mathrm{~mL}$ of $12 \mathrm{~N} \mathrm{HCl}$. The resulting solution was then diluted to $100 \mathrm{~mL}$ with deionized water (stock solution). Immediately, $5 \mathrm{~mL}$ of the stock solution was transferred to another $100-\mathrm{mL}$ volumetric flask and then made up to $100 \mathrm{~mL}$ (sample solution). A 7-mL aliquot of the $12 \mathrm{~N} \mathrm{HCl}$ was then added to the sample solution to prevent precipitation. Elemental concentration was determined with a PerkinElmer $\mathbf{5 0 0 0}$ atomic absorption spectrophotometer.

Surface area measurements were done volumetrically. For the surface area measurement with $\mathrm{N}_{2}$ specifically, a Micromeritics Accusorb $2100 \mathrm{E}$ instrument was used. Benzene and water used in the surface area study were purified by frequent expansion-pumping cycles in the vacuum manifold. The surface areas were calculated based on BET theory. The adsorption and desorption isotherms were obtained on a Cahn TG-121 system with sensitivity on the order of $0.1 \mu \mathrm{g}$.

Powder X-ray diffraction (XRD) patterns were obtained on a Philips PW 1840 automated powder diffractometer, employing Ni-filtered Co $\mathrm{K} \alpha$ radiation. Infrared (IR) spectra were recorded on a Perkin-Elmer 983 spectrometer. The spectra were taken in a form of $\mathrm{KBr}$ pellets. Thermogravimetric analysis (TGA) was carried out on a Du Pont 951 TGA analyzer. The analysis was monitored and controlled by an on-line computer system. In this technique, about $15 \mathrm{mg}$ of the sample was heated in a stream of carrier gas at $10^{\circ} \mathrm{C} / \mathrm{min}$. The carrier gas flow rate used was $100 \mathrm{~mL} / \mathrm{min}$.

\section{Results and Discussion}

Synthesis and Characterization of Na-Buserite. The reaction pathways for the synthesis of $\mathrm{Na}$-buserite from $\mathrm{MnCl}_{2}$ were described elsewhere. ${ }^{16,21}$ Thus, in alkaline medium, $\mathrm{MnCl}_{2}$ was oxidized by $\mathrm{O}_{2}$ through $\mathrm{Mn}(\mathrm{OH})_{2}$ to $\mathrm{Mn}_{3} \mathrm{O}_{4}$, which was an intermediate in the synthesis of $\mathrm{Na}$-buserite. ${ }^{21}$ As $\mathrm{NaOH}$ was used as a base in this synthetic method, the as-synthesized buserite contained interlayer $\mathrm{Na}^{+}$ions as the major charge balancing

(21) Lee, Y. C. M.Sc. Thesis, National Taiwan University, Taipei, Taiwan, 1990. cations. Na-buserite obtained in this way was a black precipitate. Its identity was confirmed by its XRD pattern and IR spectrum with reference to the literature data. ${ }^{12,22}$

The unit cell formula for the synthetic $\mathrm{Na}$-buserite here is tentatively chosen as $\mathrm{Na}_{4} \mathrm{Mn}_{14} \mathrm{O}_{26} \cdot x \mathrm{H}_{2} \mathrm{O}$. This formula gives a $\mathrm{Na} / \mathrm{Mn}$ ratio of 4/14. The $\mathrm{Na}$-buserite samples that we prepared showed an average ratio of $4.2 / 14$, which is similar to the literature value. The experimentally determined $\mathrm{O} / \mathrm{Mn}$ ratio of about $30 / 14$ is higher than the expected value of $26-27 / 14$. As the amount of oxygen atoms in the samples is determined by subtracting the weight of $\mathrm{Na}$ and $\mathrm{Mn}$ from the total dry weight used for the elemental analysis, the observed difference is assumed to be due to the strongly adsorbed water and/or impurities.

The average cation-exchange capacities, abbreviated as CEC, were determined to be 322 and 232 mequiv $/ 100 \mathrm{~g}$, on the basis of $\mathrm{Mg}$ and $\mathrm{K}$ uptake, respectively. These results show that $\mathrm{Mg}^{2+}$ is a more efficient cation exchanger than $\mathrm{K}^{+}$, which may be related to the greater charge/radius ratio. The higher ionic potential make $\mathrm{Mg}^{2+}$ more effective in layer-charge neutralization. On the basis of $\mathrm{K}$ uptake, the $\mathrm{CEC}$ value compared well with the value reported by Golden et al. ${ }^{12}$ of 240 mequiv $/ 100 \mathrm{~g}$. The CEC value on the basis of $\mathrm{Mg}$ uptake, however, is closer to the theoretical value of 313 mequiv $/ 100 \mathrm{~g}$, calculated from the unit cell formula of $\mathrm{Na}$-buserite. Thus, using $\mathrm{Mg}^{2+}$ as cation exchanger will provide a more accurate assessment on the layer-charge density of $\mathrm{Na}-$ buserite than $\mathrm{K}^{+}$.

Preparation of Pillared Buserite. The interlayer distances of a layered compound can be determined from the first low-angle diffraction peak in the XRD diffractogram. The interlayer distance of the fully dehydrated $\mathrm{Na}$-buserite is about $7 \AA$ as shown in Figure 2a. Using the known diameter of the $\mathrm{Na}^{+}$ion $(1.94$ $\AA$ ), the basal thickness of $\mathrm{Na}$-buserite could be estimated, i.e., $5.06 \AA$. The diameter of Keggin ion, abbreviated as $\mathrm{Al}_{13}$, has been determined both by theoretical means ${ }^{23}$ and by small angle scattering ${ }^{24}$ to be about $8.6 \AA$. Therefore, even if the $\mathrm{Na}$-buserite was fully hydrated during the exchange process, the free interlayer spacing of $4.94 \AA$ is still too small for $\mathrm{Al}_{13}$. Hence, it is understandable that a direct exchange of $\mathrm{Al}_{13}$ for $\mathrm{Na}^{+}$ions in $\mathrm{Na}-$ buserite will not be successful. This was found to be experimentally

(22) Potter, R. M.; Rossman, G. R. Am. Mineral 1979, 64, 1199

(23) Johansson, G. Acta Chem. Scand. 1960, 14, 769, 771.

(24) Rausch, W, V.; Bale, H. D. J. Chem. Phys. 1964, 40, 3391. 
true. A stepwise process was then deviced to improve the viability of this pillaring technique, as shown in Scheme II.

The stepwise exchange technique utilizes the $n$-hexylammonium ion, abbreviated as HA, to expand the interlayer spacing, i.e., from 10 to about $18 \AA$. This value is well fitted in the empirical equation shown by Golden et al. ${ }^{12}$ During the exchange process, the molecular axis of HA is probably oriented parallel to the plane of the buserite layers so that diffusion into the interlayers is possible. As more and more $\mathrm{HA}$ ions are accommodated inbetween the layers, the HA ions should line up with their ammonium ion heads pointing toward the basal layers. The XRD pattern of HEB is shown in Figure $2 \mathrm{~b}$. In the preparation of HEB, both the one-step and the two-step exchange processes gave the same intensity of the 18- $\AA$ peak. The resultant free spacing of about $12.9 \AA$ provides less steric restriction for $\mathrm{Al}_{13}$ to diffuse into the interlayers. Since alkyl chains grow by $1.27 \AA$ per added carbon, the free spacing of $12.9 \AA$ suggests that the interlayer HA formed double layers with the ammonium ion heads pointing toward the basal layers. Assuming that the ends of the alkyl chains in both layers are lying side by side, the inclination angle of the alkyl chains to the basal plane is estimated to be at about $52^{\circ}$. This angle is lower than the actual angle of $72^{\circ}$, calculated from the actual growth of the basal spacing per added carbon. ${ }^{12}$ This means that the alkyl chains in the top and bottom layers of the bilayer overlap each other to some extent.

The presence of HA in the interlayers of HEB is further supported by the observed IR bands in the $\mathrm{C}-\mathrm{H}$ stretching ( 2953 and $\left.2922 \mathrm{~cm}^{-1}\right)$ and bending (1490 and $1463 \mathrm{~cm}^{-1}$ ) regions.

$\mathrm{KPB}$ was prepared from $\mathrm{HEB}$ via cation-exchange with $\mathrm{Al}_{13}$ solution. The XRD pattern of the sample after the exchange process (Figure $2 \mathrm{c}$ ) showed a shift of the first peak to $16.8 \AA$. The base of this peak broadened, and a shoulder was observed at an interlayer spacing of about $14 \AA$. When the KPB sample was calcined in air at $300^{\circ} \mathrm{C}$, the $16.8-\AA$ peak vanished and a small peak was observed at interlayer spacing of $14.4 \AA$ as shown in Figure $2 \mathrm{~d}$. The calcination process burned away interlayer organic species, and revealed the $14-\AA$ peak, which was attributed to the layer distance of aluminium Keggin ion-pillared buserite. Only one original $\mathrm{Na}$-buserite peak at $2.43 \AA$ remained after calcination. The interlayer spacing of $14 \AA$ corresponds closely to the sum of the basal thickness of $\mathrm{Na}$-buserite and the diameter of $\mathrm{Al}_{13}$, i.e., $13.66 \AA$. It provides the first indication to the presence of $\mathrm{Al}_{13}$ in the interlayers.

Different preparation conditions for KPB were examined, such as temperature, exchange period, Keggin ion concentration, etc. Unfortunately, the influence of the reaction conditions on the quality of KPB was ambiguous, due to the low intensity of the $14-\AA$ peak. The quality of both the HEB and KPB compounds was based on the intensity of the first low-angle XRD peak. However, a higher concentration of $\mathrm{Al}_{13}$ in the exchange solution did not produce a better KPB, with pillars uniformly distributed in the interlayers. Moreover, it was observed that the quality of HEB played a limiting role on the quality of KPB.

Elemental analysis was carried out on the KPB samples prepared from different concentrations of $\mathrm{Al}_{13}$ solutions. The percentage of the cation-exchange sites in $\mathrm{KPB}$ occupied by $\mathrm{Al}_{13}$ are all greater than $100 \%$ (by $<30 \%$ ), assuming that $\mathrm{Al}_{13}$ is the only species present on KPB. However, in aqueous solution, $\mathrm{Al}_{13}$ can be hydrolyzed to other $\mathrm{A} 1_{13}$ species with lower charge e.g. from $7+$ to $6+$ and $5+$, with liberation of $\mathrm{H}^{+} .3,25$ This can explain the abnormally high percentage of the exchange sites occupied by $\mathrm{Al}_{13}$. Besides, adsorption of polynuclear species may take place concurrently with the ion-exchange process.

BET Surface Area and Porosity of Na-Buserite and KPB. The surface areas of $\mathrm{Na}$-buserite and KPB determined with different adsorbates are given in Table I. The surface areas of $\mathrm{Na}$-buserite determined with $\mathrm{N}_{2}$ range from 42 to $72 \mathrm{~m}^{2} / \mathrm{g}$. These values are higher than that of Cornell and Giovanoli ${ }^{16}$ of $8 \mathrm{~m}^{2} / \mathrm{g}$ on a recrystallized sample. The kinetic diameter of the $\mathrm{N}_{2}$ molecule is

(25) Bottero, J. Y.; Cases, J. M.; Fiessinger, F.; Poirier, J. E. J. Phys. Chem. $1980,84,2933$
Table I. Surface Areas of $\mathrm{Na}-\mathrm{Buserite}(\mathrm{Na}-\mathrm{B})$ and KPB with Different Adsorbates

\begin{tabular}{lll}
\hline \multicolumn{1}{c}{ sample $^{a}$} & adsorbate & surface area, $\mathrm{m}^{2} / \mathrm{g}$ \\
\hline $\mathrm{Na}-\mathrm{B}$ & nitrogen & $42-72$ \\
& benzene & 54 \\
& water & 235 \\
$\mathrm{KPB}(1)-500^{\circ} \mathrm{C}$ & argon & 55 \\
$\mathrm{KPB}(1)$ & nitrogen & 151 \\
$\mathrm{KPB}(2)$ & nitrogen & 134 \\
& nitrogen & 142 \\
& benzene & 97 \\
& water & 81 \\
& argon & 115
\end{tabular}

${ }^{a} \mathrm{KPB}$ samples were all precalcined at $300^{\circ} \mathrm{C}$ except as otherwise indicated. All the samples were dehydrated at $140-160^{\circ} \mathrm{C}$ before the surface area measurement. The concentration of the exchange solutions in KPB preparation is (1) $1.0 \mathrm{~N}$ and (2) $0.6 \mathrm{~N}$.

$3.64 \AA .26$ Therefore, the free spacing of $\mathrm{Na}$-buserite of $1.94 \AA$ in the dehydrated form cannot allow the $\mathrm{N}_{2}$ molecules to enter the interlayers. Hence, only the external surface area was measured. Thus, the higher surface area of Na-buserite compared to literature values indicates that the layered structure may be in smaller fragments.

The surface area of $\mathrm{Na}$-buserite determined with benzene is comparable to that with $\mathrm{N}_{2}$; the slightly lower value can be explained in term of localized adsorbed benzene molecules with poor packing as a result of the strong interaction between their $\pi$ electron clouds. The surface area determined with water is far higher than these two values. The kinetic diameter of the water molecule is $2.65 \AA$ and is larger than the interlayer free spacing of dry $N_{1}$-buserite. The electrostatic field between the framework oxide anions and the extra-framework $\mathrm{Na}^{+}$cations must be strong, in order to force the polar water molecules into the interlayers. The driving force should be an ion-dipole interaction between the electrostatic field of $\mathrm{Na}$-buserite and water molecules. This electrostatic field is quite high judging from the CEC data and is thus responsible for the ready hydration of $\mathrm{Na}$-buserite.

The KPB samples calcined at $300{ }^{\circ} \mathrm{C}$ showed an increase of about $100 \%$ in surface area compared to $\mathrm{Na}$-buserite. A control experiment by exchanging $\mathrm{HEB}$ with $1 \mathrm{~N} \mathrm{NaCl}$ solution showed only a slight increase in surface area, i.e. from 42 to $52 \mathrm{~m}^{2} / \mathrm{g}$. When the same batch of HEB sample was used for the pillaring reaction, the product obtained gave a surface area of $133 \mathrm{~m}^{2} / \mathrm{g}$. Therefore, the large increase in surface area of KPB is definitely due to the pillaring of the layers. The results also showed that a higher concentration of Keggin ion exchange solution did not yield a KPB sample of higher surface area. Both benzene and water adsorption gave much lower surface areas than $\mathrm{N}_{2}$. This effect cannot be fully explained by the blocking and steric hinderance effects by the pillars, as the surface area determined using water is lower than those determined using $\mathrm{N}_{2}$ and benzene. However, if water or benzene chemisorbs on the pillars, it will block the entrance of incoming molecules into the inner space of the interlayers. This is possible since the Keggin ion that form the pillars has a bulky structure, as had been proposed by Johansson. ${ }^{23,25}$ If the pillars are located near the entrance of the interlayers, the assumed phenomena may cause even greater drop in surface area. It should be noted also that the surface area determined with water for KPB is much smaller than that of $\mathrm{Na}$-buserite, although the free interlayer spacing of KPB is much larger than that of Na-buserite. This result immediately suggests a lower electrostatic field in KPB. The replacement of $\mathrm{Na}^{+}$cations by the $\mathrm{Al}_{13}$ pillars resulted in a smaller electronegativity difference between extra-framework cations and framework oxide anions. Thus, the interaction between the electrostatic field and the dipole of water molecules is smaller, which resulted in less hydration.

The surface areas measured with Ar (kinetic diameter $=3.40$ $\AA$ ) are consistently lower than those measured with $\mathrm{N}_{2}$. This may be related to the difference in shapes of $\mathrm{Ar}$ and $\mathrm{N}_{2}$ and thus their

(26) Breck, D. W. Zeolite Molecular Sieves; Wiley: New York, 1973; p 636. 


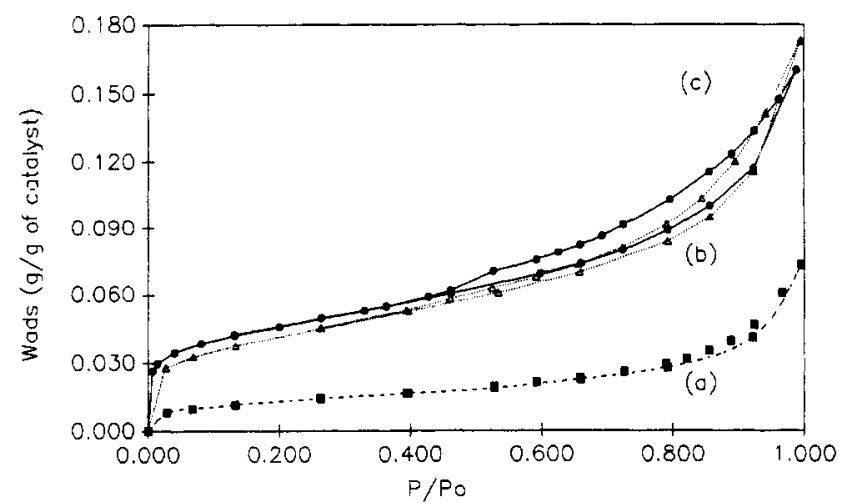

Figure 3. $\mathrm{N}_{2}$ adsorption-desorption isotherms of (a) $\mathrm{Na}$-buserite (b) KPB-50, and (c) KPB-70.

Table II. IR Absorption Frequencies of Na-Buserite and KPB

\begin{tabular}{lccccccc}
\hline sample & $T_{\mathrm{p}}{ }^{a}{ }^{\circ} \mathrm{C}$ & \multicolumn{5}{c}{ frequency, $\mathrm{cm}^{-1}$} \\
\cline { 3 - 8 } $\mathrm{Na}-\mathrm{B}^{b}$ & $\ldots$ & 633 & 512 & 480 & 421 & 359 & 227 \\
$\mathrm{Na}-\mathrm{B}$ & $\ldots$ & 630 & 512 & 477 & 414 & 359 & 215 \\
$\mathrm{Na}-\mathrm{B}$ & 300 & & & 509 & 445 & & 238 \\
$\mathrm{Na}-\mathrm{B}$ & 500 & & 555 & 468 & 417 & 307 & 204 \\
$\mathrm{KPB}$ & $\ldots$ & Sh $^{c}$ & 511 & 481 & 426 & & \\
$\mathrm{KPB}$ & 300 & & 543 & & & & 215 \\
$\mathrm{KPB}$ & 500 & & 557 & & & & 216
\end{tabular}

${ }^{a} T_{\mathrm{p}}$ is the pre-calcined temperature. ${ }^{b}$ Data taken from ref $12 .{ }^{\mathrm{c}} \mathrm{Sh}$ $=$ shoulder.

packing behavior on the surface. However, they gave similar surface area ratios for KPB to $\mathrm{Na}$-buserite.

The KPB sample retained its structure when calcined in air at $500^{\circ} \mathrm{C}(2 \mathrm{~h})$ and gave a comparable surface area to that of the sample calcined at $300^{\circ} \mathrm{C}$. In addition, the XRD pattern of KPB calcined at $500^{\circ} \mathrm{C}$ showed that the pillars remained intact.

The $\mathrm{N}_{2}$ adsorption-desorption isotherms for various samples are shown in Figure 3. The number associated with KPB samples is the exchange temperature. Other than the weight of $\mathrm{N}_{2}$ adsorbed ( $W_{\text {ads }}$ ), the isotherms for KPB-70 and KPB-50 are similar. The surface area of KPB-70 is slightly higher than that of KPB-50. Thus, $70^{\circ} \mathrm{C}$ is a better exchange temperature to prepare a pillared sample of higher surface area. Only small amount of hysteresis, which corresponded to a mesoporous structure, was observed on both isotherms. Hence, the pillaring process produced KPB samples with a large proportion of micropores. On the other hand, although $\mathrm{Na}$-buserite also showed microporous adsorption-desorption behavior, the amount of $\mathrm{N}_{2}$ adsorbed was negligible.

Thermal Stability of Na-Buserite and KPB. (i) Infrared Study. The IR spectra and data for $\mathrm{Na}$-buserite upon calcination at different temperatures are shown in Figure $4 \mathrm{~A}$ and Table II respectively. The IR bands in the lattice vibrational region $\left(200-1400 \mathrm{~cm}^{-1}\right)$ of $\mathrm{Na}$-buserite are similar to those obtained by Potter and Rossman.22

Progressively dehydrating the $\mathrm{Na}$-buserite by heating in air at higher temperatures caused a corresponding decrease in the crystallinity of the sample. The spectrum obtained after calcination at $300^{\circ} \mathrm{C}$ is similar to that of birnessite, suggesting that only dehydration occurred. Na-birnessite, with unit cell formula $\mathrm{Na}_{4} \mathrm{Mn}_{14} \mathrm{O}_{26} \cdot 9 \mathrm{H}_{2} \mathrm{O}$ is the partially dehydrated product of $\mathrm{Na}-$ buserite. At this temperature, considerable broadening of IR bands occurred, indicating a higher degree of disorder than that observed at room temperature. The peaks shifted slightly to higher frequencies. The diffuse nature of the peaks has been attributed to some degree of disorder in the stacking of $\mathrm{MnO}_{6}$ sheets. ${ }^{16}$ Consistently, the XRD peaks became very weak and diffuse. This behavior, however, is quite reversible as readsorption of water (19 h) partially reproduced its original intensity. Hence, $\mathrm{Na}$-buserite was mainly in a disordered state when calcined at $300^{\circ} \mathrm{C}$.

Upon calcination at $500^{\circ} \mathrm{C}$, new bands appeared, indicating the formation of new compounds. These observations are in line with the results of XRD (refer to part ii). Similarly, Golden et
(A)
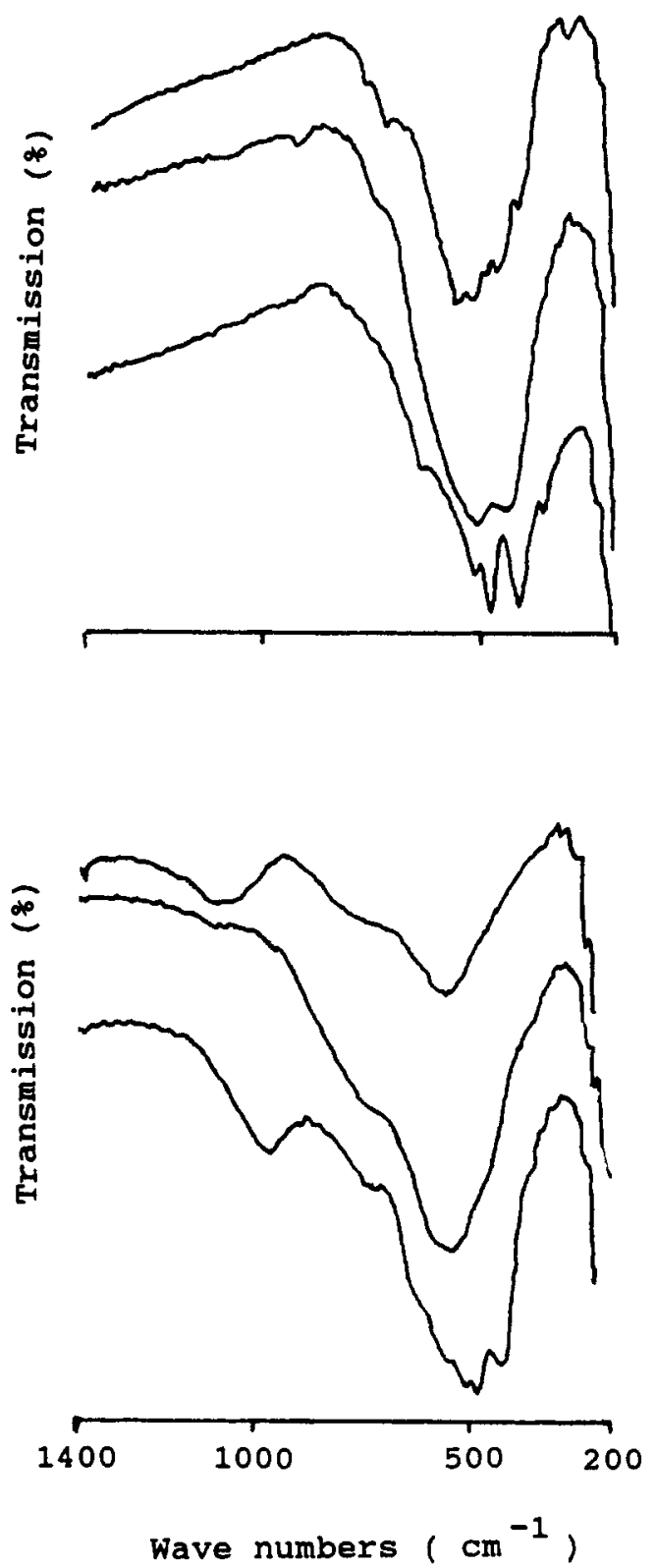

Figure 4. IR spectra of (A) Na-buserite and (B) KPB on calcination at (a) 25 , (b) 300 , and (c) $500^{\circ} \mathrm{C}$.

al. ${ }^{12}$ observed that transformations of the layered birnessite into other species took place via a disorder state at about $200-400^{\circ} \mathrm{C}$.

The IR spectra of the KPB samples on calcination at different temperatures are shown in Figure 4B. The corresponding frequencies are shown in Table II as well. As can be seen, the spectrum of KPB before calcination is slightly different from that of $\mathrm{Na}$-buserite in the lattice vibrational region. The difference is not due to the replacement of $\mathrm{Na}^{+}$by $\mathrm{HA}$, since $\mathrm{Na}$-buserite and HEB have identical spectral features in the lattice vibrational region. It may not arise from the replacement of $\mathrm{Na}^{+}$by $\mathrm{H}^{+}$, which could take place as the $\mathrm{pH}$ of the exchange solution of 4.1-4.2 is acidic. This is because Golden et al. ${ }^{12}$ have shown that IR spectra of $\mathrm{Na}$-buserite are not affected by the nature of the non-transition metal cations. Therefore, the difference must arise from the pillaring of the buserite interlayers. Calcinations at 300 and $500^{\circ} \mathrm{C}$ in air gave similar spectra, thus supporting the XRD results that no new compounds were formed. However, the broadening of peaks implies some extent of disorder in layered structure upon calcination. These spectra are similar in feature to one of the birnessite samples studied by Potter and Rossman, ${ }^{22}$ 
(A)

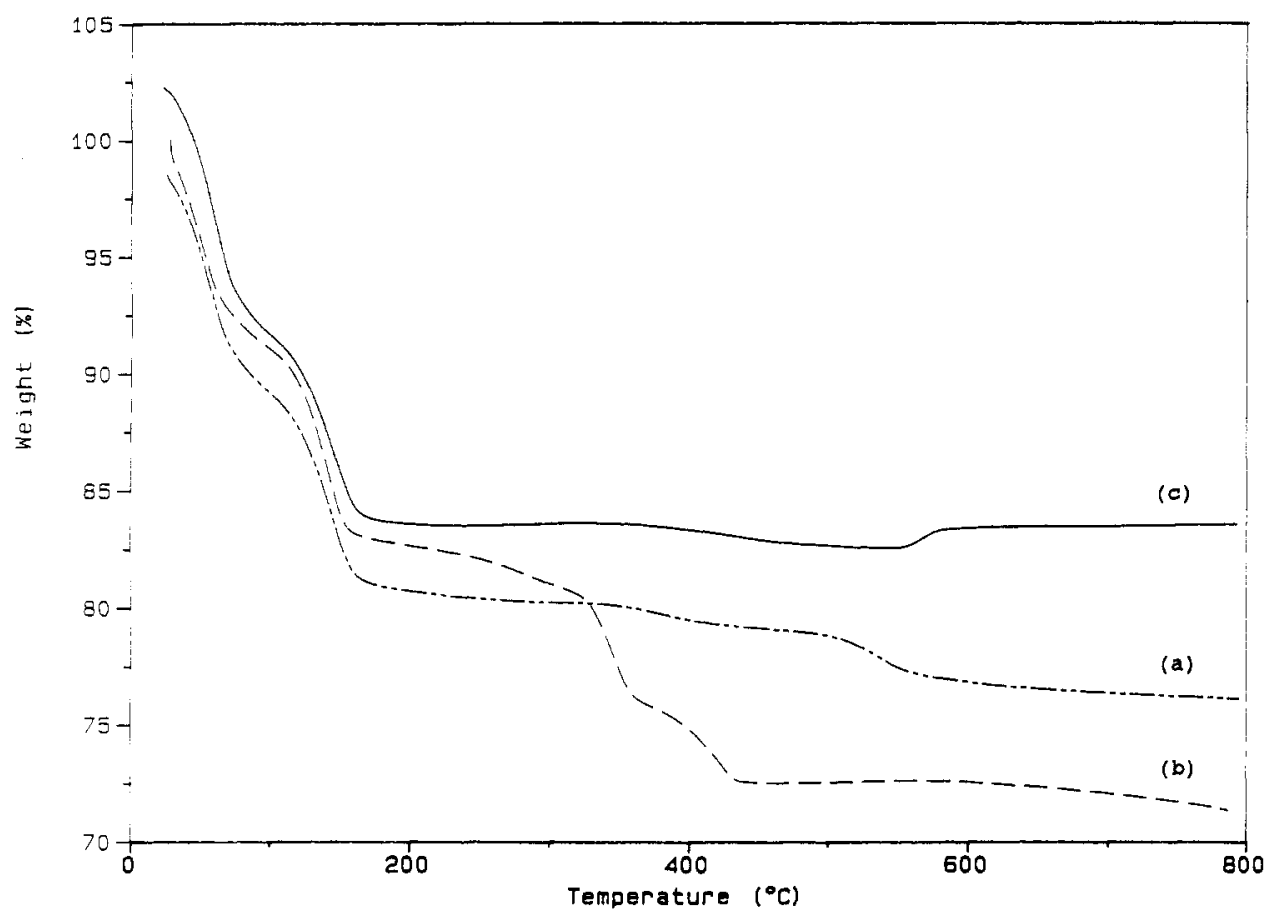

(B)

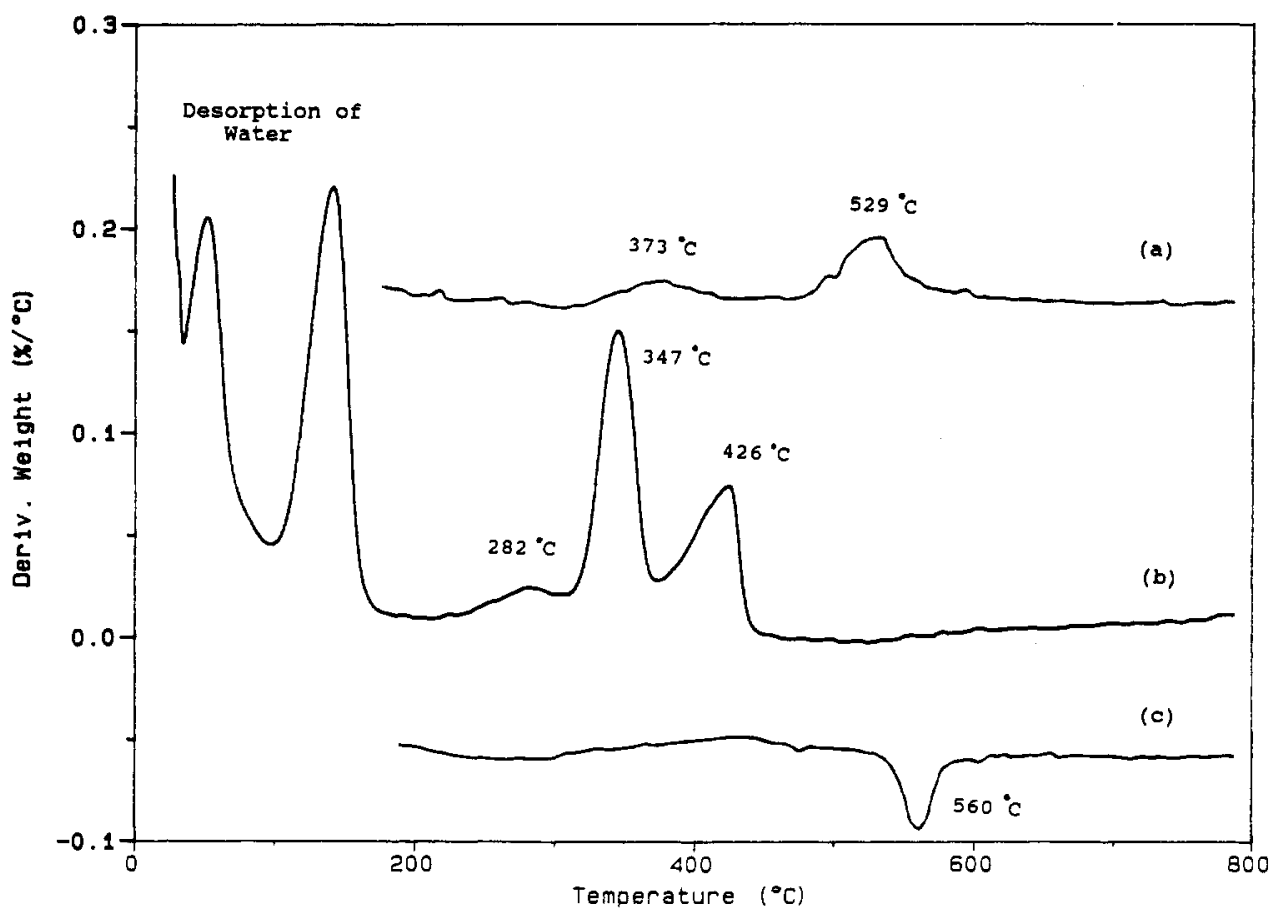

Figure 5. (A) TGA and (B) DTG profiles of $\mathrm{Na}$-buserite in (a) $\mathrm{N}_{2}$ (b) $\mathrm{N}_{2}: \mathrm{H}_{2}=9: 1$, and (c) $\mathrm{O}_{2}$.

but the frequencies of the major bands shifted slightly (about 30 $\mathrm{cm}^{-1}$ ) to higher frequency.

(ii) Complementary TGA/DTG-XRD Study. The TGA and DTG profiles of $\mathrm{Na}$-buserite in different gaseous environment are shown in parts A and B of Figure 5, respectively. For the purpose of clarity, these profiles and that of Figure 6 were shifted along the $y$-axis. Thus, only the relative magnitude should be considered. The transformation of $\mathrm{Na}$-buserite in various gaseous environments is also summarized in Scheme III.

In an $\mathrm{N}_{2}$ environment, the first two DTG (percentage weight loss per ${ }^{\circ} \mathrm{C}$ ) peaks are due to the desorption of physisorbed and chemisorbed water, respectively. These peaks are omitted in subsequent discussion. The small peak at $373^{\circ} \mathrm{C}$ is probably due to the slight loss of lattice oxygen, since it became less distinct
Scheme III. Transformation of $\mathrm{Na}$-Buserite

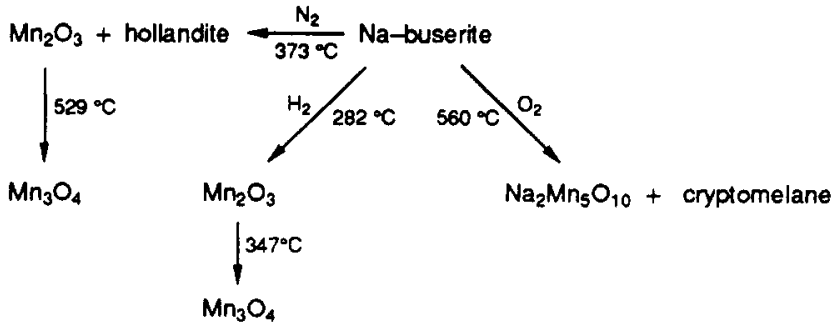


(A)

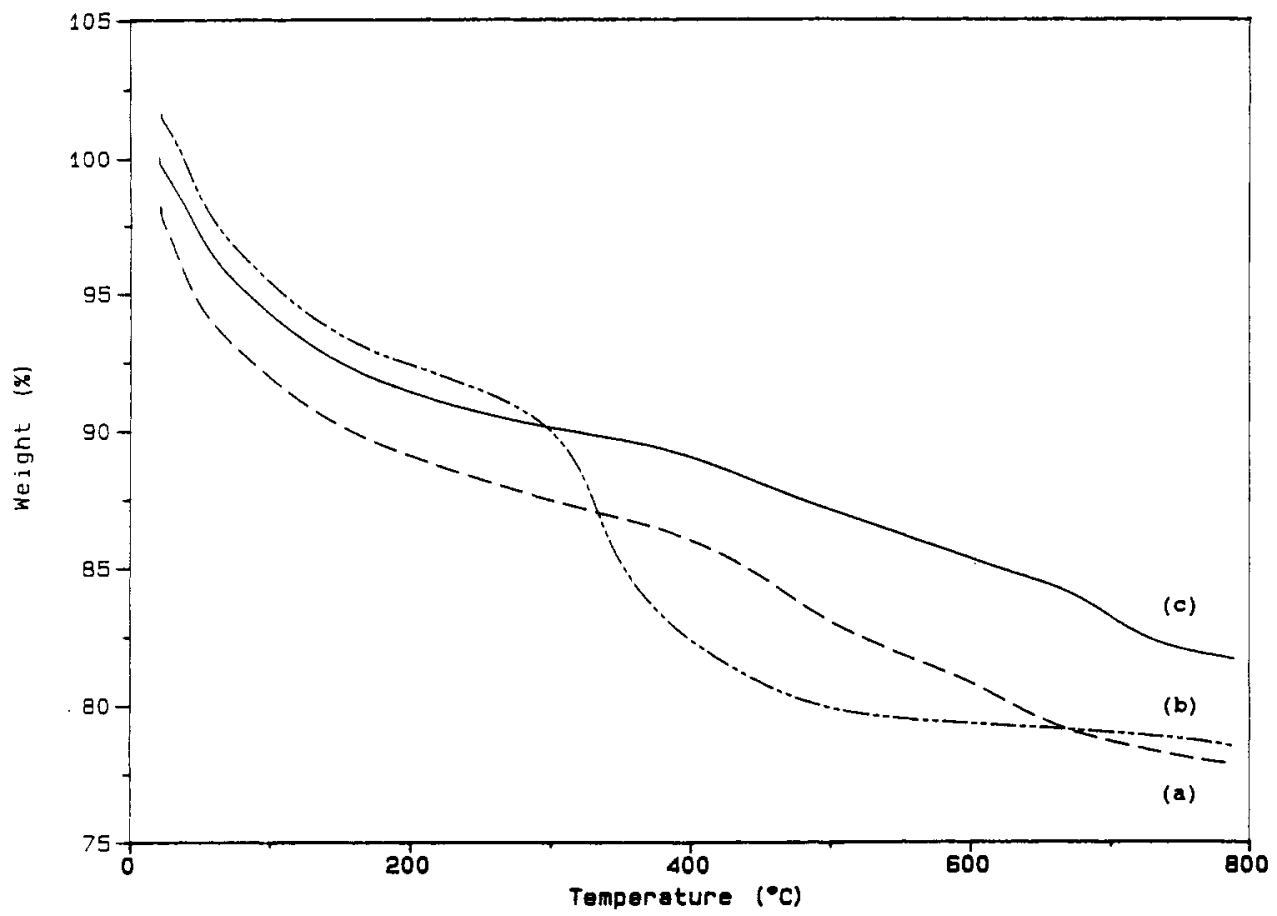

(B)

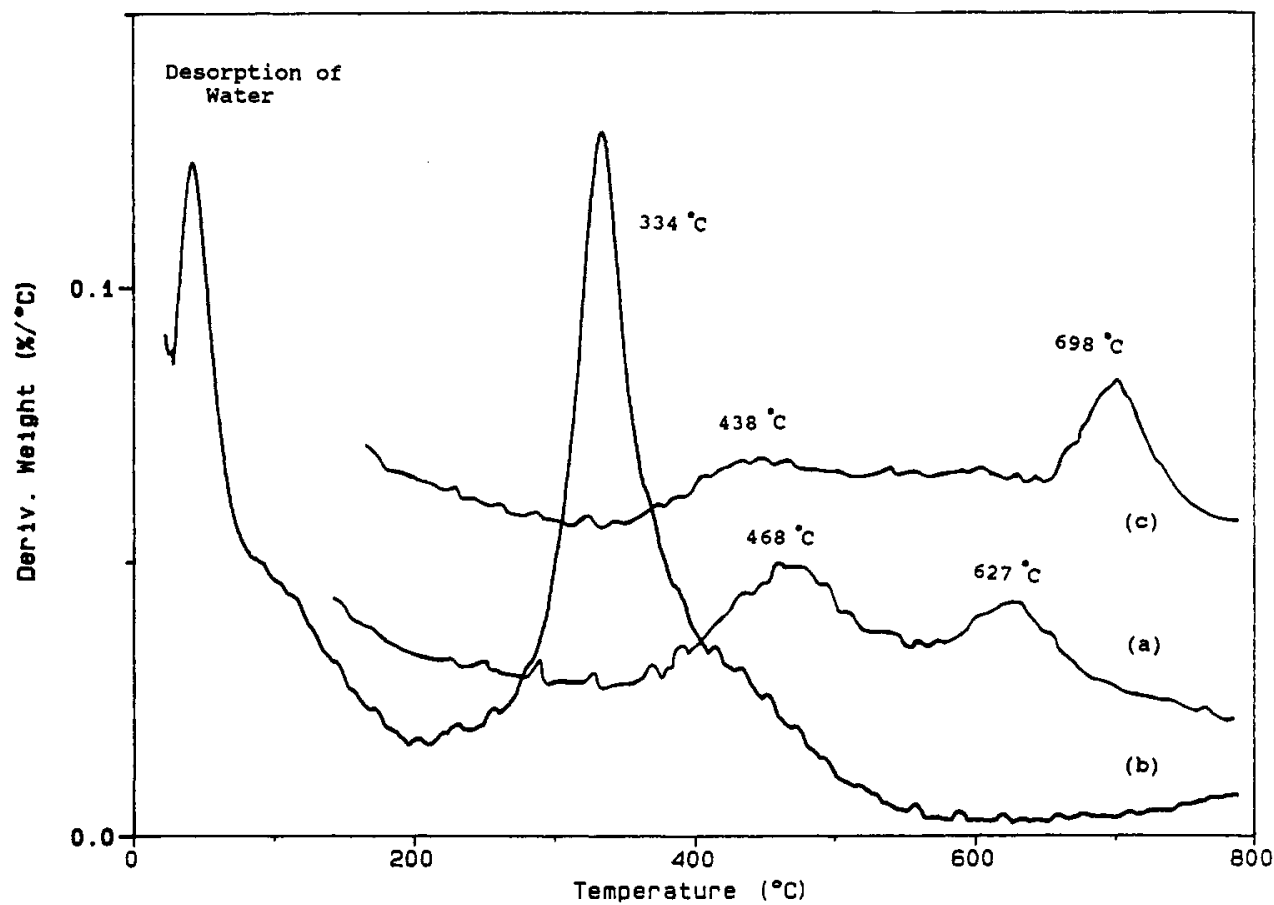

Figure 6. (A) TGA and (B) DTG profiles of KPB in (a) $\mathrm{N}_{2}$, (b) $\mathrm{N}_{2}: \mathrm{H}_{2}=9: 1$, and (c) $\mathrm{O}_{2}$.

in an $\mathrm{O}_{2}$ environment. This temperature probably starts the transformation of $\mathrm{Na}$-buserite beyond the previously mentioned disorder state. From the weight loss in the TGA profile, the Mn to $\mathrm{O}$ stoichiometry of the compound(s) formed is determined to be $\mathrm{Mn}_{2} \mathrm{O}_{3.5}$. There is an uncertainty of \pm 0.1 associated with the oxygen atom. Thus, $\mathrm{Mn}_{2} \mathrm{O}_{3}$ is likely to be one of the species formed at this temperature. The other species formed should have an $\mathrm{O} / \mathrm{Mn}$ ratio greater than $\mathrm{Mn}_{2} \mathrm{O}_{3}(\mathrm{O} / \mathrm{Mn}=3 / 2)$. XRD analysis was carried out on a separate $\mathrm{Na}$-buserite sample heated in $\mathrm{N}_{2}$ at $320^{\circ} \mathrm{C}$ for $2 \mathrm{~h}$ and showed the formation of a species belonging to the hollandite group (possibly hollandite). Hollandite, with $\mathrm{O} / \mathrm{Mn}=2,{ }^{15,22}$ meets the above requirement. It consists of $\mathrm{MnO}_{6}$ octahedra which share edges to form double chains, which then linked by share vertices forming $[2 \times 2]$ channels. The absence of conclusive evidence on the formation of $\mathrm{Mn}_{2} \mathrm{O}_{3}$ from XRD may mean that it is amorphous at this stage.

The last peak at $529^{\circ} \mathrm{C}$ is due to the formation of $\mathrm{Mn}_{3} \mathrm{O}_{4}$ (hausmannite) as detected by XRD. XRD analysis was done separately with a sample heated at $550^{\circ} \mathrm{C}$ in $\mathrm{N}_{2}$ for $2 \mathrm{~h}$. Another species detected by XRD belongs to the hollandite group, as mentioned before. Both species give XRD peaks of similar intensity. The presence of hollandite group species besides hausmannite $(O / M n=4 / 3)$ will cause the overall $O / M n$ ratio of the compounds formed to be greater than $4 / 3$. In fact, the overall $\mathrm{Mn}$ to $\mathrm{O}$ stoichiometry of the compounds formed determined from TGA is $\mathrm{Mn}_{3} \mathrm{O}_{4.9}$, which is thus consistent with the above suggestion. Hence, the overall transformation of $\mathrm{Na}$-buserite in $\mathrm{N}_{2}$ occurs with a total loss of oxygen as observed in TGA. 
Scheme IV. Transformation of KPB

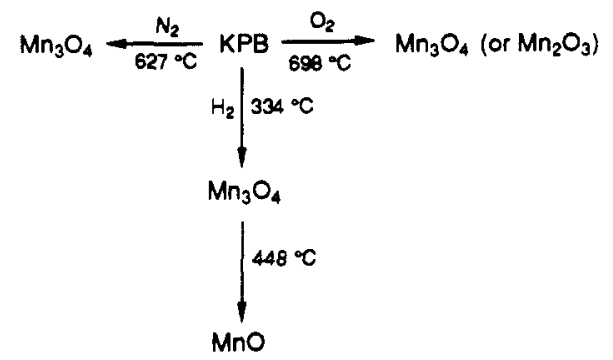

Similar intermediates may be formed during the reduction of $\mathrm{Na}$-buserite with a mixture of $\mathrm{H}_{2}$ and $\mathrm{N}_{2}$. From TGA/DTG analysis, the peaks at 282,347 , and $426^{\circ} \mathrm{C}$ can be related to the formation of $\mathrm{Mn}_{2} \mathrm{O}_{3.4}, \mathrm{Mn}_{3} \mathrm{O}_{4.1}$, and $\mathrm{MnO}_{1.1}$, respectively. The identity of the last two species was confirmed by $\mathrm{XRD}$, with samples reduced at 300 and $500^{\circ} \mathrm{C}$ for $2 \mathrm{~h}$, respectively. However, the peak at $282^{\circ} \mathrm{C}$ was not confirmed due to its small and variable magnitude. Strohmeier and Hercules ${ }^{27}$ have also shown that the reduction of $\beta-\mathrm{MnO}_{2}$ proceeds through similar pathways in an $\mathrm{H}_{2}$ atmosphere:

$$
\begin{aligned}
& \beta-\mathrm{MnO}_{2} \underset{<250^{\circ} \mathrm{C}}{\longrightarrow} \mathrm{Mn}_{2} \mathrm{O}_{3} \underset{250{ }^{\circ} \mathrm{C}}{\longrightarrow} \mathrm{Mn}_{3} \mathrm{O}_{4} \underset{>250^{\circ} \mathrm{C}}{\longrightarrow} \\
& \mathrm{MnO} \underset{>1200^{\circ} \mathrm{C}}{\longrightarrow} \mathrm{Mn}
\end{aligned}
$$

The reduction temperatures for various species, however, are lower than the temperature observed here, which may reflect different materials and heating rates.

The TGA/DTG profiles of Na-buserite do not show distinct weight losses in $\mathrm{O}_{2}$ environment. A gradual weight loss occurred between 300 and $500^{\circ} \mathrm{C}$. The calculated $\mathrm{Mn}$ to O stoichiometry of the compound(s) formed at this stage is $\mathrm{Mn}_{14} \mathrm{O}_{25.2}$; thus, only a very small amount of oxygen is lost. The DTG profile indicates an increase in weight (negative peak) at $560^{\circ} \mathrm{C}$. When a $\mathrm{Na}-$ buserite sample was calcined in $\mathrm{O}_{2}$ at $550^{\circ} \mathrm{C}$ for $2 \mathrm{~h}$, the XRD pattern showed the formation of $\mathrm{Na}_{2} \mathrm{Mn}_{5} \mathrm{O}_{10}$ with major peaks at $d=5.38,2.41$, and $4.86 \AA$. A hollandite group compound (possibly cryptomelane) was formed in smaller quantities. Hollandite and cryptomelane have the same tunnel structure but with different symmetry. ${ }^{32}$ The formation of $\mathrm{Na}_{2} \mathrm{Mn}_{5} \mathrm{O}_{10}$ and cryptomelane require an uptake of $\mathrm{O}_{2}$ by $\mathrm{Na}$-buserite, and this accounts for the negative peak. $\mathbf{M g}$-buserite, which gave only hausmannite, ${ }^{12}$ did not show this negative peak, but a DTG peak corresponds to a distinct weight loss at $629^{\circ} \mathrm{C}$. K-buserite, which gave mainly cryptomelane, ${ }^{12}$ showed this negative DTG peak at about $556^{\circ} \mathrm{C}$. These results further support the origin of the negative DTG peak at $560^{\circ} \mathrm{C}$. The amount of $\mathrm{Mn}_{3} \mathrm{O}_{4}$ formed is negligible. This explains the absence of distinct weight losses between 300 and $500^{\circ} \mathrm{C}$. Hence, the loss of oxygen from Nabuserite is negligible.

When $\mathrm{Na}$-buserite was calcined in air at $550^{\circ} \mathrm{C}$ for $2 \mathrm{~h}$, the main products formed were similar to those for $\mathrm{Na}$-buserite calcined in pure oxygen. When the sample was heated at 800 ${ }^{\circ} \mathrm{C}$, bixbyite $\left(\mathrm{Mn}_{2} \mathrm{O}_{3}\right)$ and $\mathrm{Na}_{4} \mathrm{Mn}_{9} \mathrm{O}_{18}$ were formed. The XRD pattern of the latter compound has major peaks at $d=4.55,2.63$, and $2.40 \AA$.

Thus, $\mathrm{Na}$-buserite behaves differently in different environments below $800^{\circ} \mathrm{C}$. Hydrogen tends to reduce $\mathrm{Na}$-buserite to $\mathrm{MnO}$ whereas oxygen and air tend to oxidize $\mathrm{Na}$-buserite to $\mathrm{Na}_{2} \mathrm{Mn}_{5} \mathrm{O}_{10}$ and crytomelane. However, a reduced compound $\left(\mathrm{Mn}_{2} \mathrm{O}_{3}\right)$ can be formed at high temperature. In nitrogen, a mixture of reduced $\left(\mathrm{Mn}_{3} \mathrm{O}_{4}\right)$ and oxidized (hollandite) compounds is formed.

The TGA and DTG profiles of KPB are shown in parts $A$ and $B$ of Figure 6, respectively. The transformation of KPB in various gaseous environment is also summarized in Scheme IV.

In an $\mathrm{N}_{2}$ environment, a DTG peak was observed at $468^{\circ} \mathrm{C}$, which can be assigned to the water loss as a result of condensation

(27) Strohmeier, B. R.; Hercules, D. M. J. Phys. Chem. 1984, 88, 4922. of $\mathrm{Al}_{13}$ hydroxyl groups. At $627^{\circ} \mathrm{C}$, transformation of $\mathrm{KPB}$ to $\mathrm{Mn}_{3} \mathrm{O}_{4}$ occurred as detected by XRD. Thus, the pillars must have collapsed, forming possibly $\mathrm{Al}_{2} \mathrm{O}_{3}$. The thermal stability of KPB is thus quite similar to that of $\mathrm{Al}_{13}$ pillared bentonite, which is thermally stable to $500^{\circ} \mathrm{C} .{ }^{28}$ Heating at 600 and $700^{\circ} \mathrm{C}$ caused a partial collapsed of the layered bentonite structure.

Comparison of the DTG profiles for KPB before and after calcination at $300^{\circ} \mathrm{C}$ showed that the interlayer HA decomposed at $235^{\circ} \mathrm{C}$ in $\mathrm{N}_{2}$. DTG profiles of HEB also gave the same decomposition temperature. Water is lost at a lower temperature between 37 and $43^{\circ} \mathrm{C}$ for the calcined sample, which may be the result of less blocking for desorption by $\mathrm{HA}$.

The DTG profile for KPB in an $\mathrm{O}_{2}$ environment is similar to that in $\mathrm{N}_{2}$. The structure however, collapsed at a higher temperature in $\mathrm{O}_{2}\left(698^{\circ} \mathrm{C}\right)$. When the sample was calcined in air for $2 \mathrm{~h}$ at $700^{\circ} \mathrm{C}, \mathrm{Mn}_{3} \mathrm{O}_{4}$ or $\mathrm{Mn}_{2} \mathrm{O}_{3}$ was formed. At $500^{\circ} \mathrm{C}$ however, the structure remained intact.

In an $\mathrm{H}_{2}$ environment, there are two peaks observed in the DTG profile centered at 334 and $448{ }^{\circ} \mathrm{C}$. The latter peak is not always well resolved. It was found from XRD for a sample reduced at $600^{\circ} \mathrm{C}$ for $2 \mathrm{~h}$ that the product of reduction was a mixture of $\mathrm{Mn}_{3} \mathrm{O}_{4}$ and $\mathrm{MnO}$, with $\mathrm{MnO}$ as the minor component. Qualitatively, the amount of $\mathrm{MnO}$ formed is far less for KPB than for $\mathrm{Na}$-buserite at a similar reduction temperature.

The results obtained from the complementary studies between TGA/DTG and XRD techniques showed that KPB is relatively more stable than $\mathrm{Na}$-buserite in all of the gaseous environments studied. These results also showed that KPB is stable in air in excess of $600^{\circ} \mathrm{C}$. Thus, the pillars in the interlayers improve the thermal stability of the buserite structure.

\section{Conclusion}

The results showed that KPB can be prepared via an ion-exchange process from $\mathrm{Na}$-buserite. However, the free spacing of the $\mathrm{Na}$-buserite has to be expanded with $n$-hexylammonium ions prior to the introduction of Keggin ions between the layers. XRD gave convincing evidence on the presence of pillars in the interlayers. The low intensity of the first diffraction peak at $14 \AA$ indicates that the pillars are not uniformly distributed and/or not many pillars are introduced between the layers. It must be mentioned that the XRD patterns were obtained with unoriented samples.

The success of pillaring $\mathrm{Na}$-buserite was also confirmed by a surface area study, TGA, and IR spectroscopy. Unlike $\mathrm{Na}$ buserite, surface area measurement on KPB showed that the interior of the interlayers are now accessible to molecules as large as benzene. $\mathrm{N}_{2}$ adsorption-desorption studies revealed the microporous nature of KPB. TGA on the other hand has indicated an improved thermal stability of KPB to $\mathrm{Na}$-buserite in all gaseous environments. The pillars in KPB are stable up until $600-700$ ${ }^{\circ} \mathrm{C}$ in either an $\mathrm{N}_{2}$ or an $\mathrm{O}_{2}$ environment. Beyond these temperatures, the pillars collapsed and $\mathrm{Mn}_{3} \mathrm{O}_{4}$ (or $\mathrm{Mn}_{2} \mathrm{O}_{3}$ ) was formed from the buserite structure.

Unfortunately, in an $\mathrm{H}_{2}$ environment, KPB transformed to a mixture of $\mathrm{Mn}_{3} \mathrm{O}_{4}$ and $\mathrm{MnO}$. The transformation began at about $300{ }^{\circ} \mathrm{C}$. This process may occur as a result of reduction of the buserite framework. Therefore, KPB is not suitable for use as a catalyst or a catalyst support for reactions involving $\mathrm{H}_{2}$, such as $\mathrm{CO}$ hydrogenation. KPB exhibits better thermal stability in an environment where $\mathrm{O}_{2}$ is present.

A preliminary study on oxy-dehydrogenation of ethane showed that KPB performed better than $\mathrm{Na}$-buserite. The activity is higher in KPB but the selectivity to ethene is comparable. The observed increase in activity must be due to the pillaring of the layered structure of buserite. This topic will be further investigated and reported in a separate article.

Acknowledgment. Financial support from the National Science Council of the Republic of China is gratefully acknowledged.

(28) Occelli, M. L. Ind. Eng. Chem. Prod. Res. Dev. 1983, 22, 553 